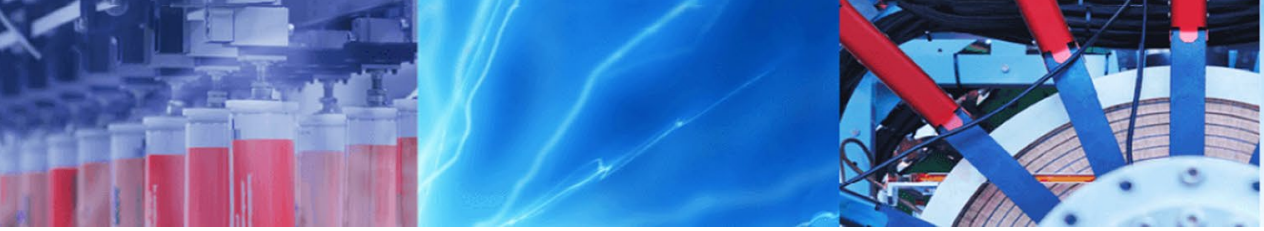

Short Communication

\title{
Rapid hydrogen generation from cotton wastes by mean of dark fermentation
}

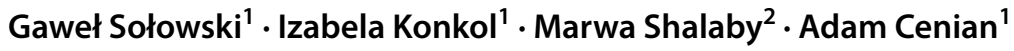

Received: 9 January 2020 / Accepted: 23 July 2020 / Published online: 28 July 2020

(C) The Author(s) $2020 \quad$ OPEN

\begin{abstract}
Dark fermentation of textile wastes is discussed in the paper. In the experiment cotton wastes were fermented. Before fermentation the cotton was hydrolyzed using $0.1 \mathrm{M} \mathrm{HCl}$ acidic solution. The inoculum was pretreated by means of heat shock for $0.5 \mathrm{~h}$ at $105^{\circ} \mathrm{C}$. The fermentation was carried out under mesophilic conditions at a load of $5 \mathrm{~g} \mathrm{VSS} / \mathrm{L}$, and pH 5 . Oxygen was added in small quantities during fermentation. The oxygen flow rates (OFR) were between 0.3 and $1.0 \mathrm{~mL} / \mathrm{h}$. The fermentation was carried out for a few days at temperatures between 40 and $43^{\circ} \mathrm{C}$. Hydrogenesis prevailed at the lower temperature $\left(40^{\circ} \mathrm{C}\right)$ and methanogenesis at the higher $\left(43^{\circ} \mathrm{C}\right)$. Conversion of cotton waste to methane $(3.4 \%)$ was slightly higher than conversion to hydrogen (2.6\%). The highest hydrogen production was obtained for OFR $0.8 \mathrm{~mL} / \mathrm{h}$ and the percentage of hydrogen in biogas was $43 \%$. At higher temperatures $\left(43^{\circ} \mathrm{C}\right)$ no hydrogen production was observed
\end{abstract}

Keywords Dark fermentation $\cdot$ Hydrogen $\cdot$ Methane $\cdot$ Cotton

\section{Introduction}

Cotton waste constitute a high proportion of textile wastes, which account for $50 \%$ of world biomass waste [1]. Its utilization, complying with demands of circular economy, can solve a problem especially in the Middle East, including Syria [2] but also in Europe [3]. Poland generates around $236661 \mathrm{Mg}$ of cotton waste annually, which is clearly a huge amount to process [4]. On the other hand, there exists a high demand for energy [5] and industrial raw materials [6], that increasingly will not be easily met by fossil resources [7]. So, the role of renewable fuels like hydrogen produced from biomass will grow continuously [8]. Cotton plantations can contribute to global world sustainability [9], oil from its seeds may serve as biofuel or lubricant [10,11], and cotton wastes may be transformed into biodiesel $[12,13]$ or as an additive to other biofuels $[14,15]$ with properties similar to FAME [16]. Cotton wastes are used for PET or insulating material production [17] or serve as important substrate for pyrolysis $[16,17]$.

An interesting issue, undertaken in this research, is related to the possibility of using cotton waste, including cotton stalk [18] as a source of hydrogen. Fast depletion of fossil fuels [19] means that there is a growing need to seek renewable ways of hydrogen production, an important resource for chemistry [20] and carbon free fuel [8]. Taherzadeh works $[2,21]$ proved that cotton wastes are a good source of methane generation, but the process includes expensive chemical pretreatment using NMMO, highly concentrated sulfuric acid or sodium hydroxide [2, 22]. But the alternative dark fermentation (DF) process may lead to biohydrogen production [23]. DF process, a truncated anaerobic digestion (without final methanisation), converts substrates into gaseous products like hydrogen, carbon dioxide and volatile organic acids (e.g. butyric, acetic or propionic) [24].

Gaweł Sołowski, gsolowski@imp.gda.pl | 'Institute of Fluid-Flow Machinery of Polish Academy of Sciences, Gdańsk, Poland. ${ }^{2}$ Department of Chemical Engineering and Pilot Plant, National Research Center in Cairo, Cairo, Egypt. 
According to initial assessments, cotton waste could be a potential source of hydrogen [25]. The aim of this research is to determine the optimal conditions for hydrogen production in the DF process, and its industrial scale viability, with a focus on the effect of temperature variation in the mesophilic range on hydrogen production from cotton waste. Similar studies were performed by Chandra et al. [26] for rice straw anaerobic fermentation. As in earlier research [27], related to sour cabbage fermentation, microaeration (which stimulates hydrogen production) was applied.

Lack of information on successful scaling up of DF processes [28] (except possibly [29] leads Carrillo-Reyes et al. [30] to state that even lower efficiency (15\% of practical hydrogen yield) could be considered as feasible. In most cases the optimal dark fermentation process proceeds under acidic conditions ( $\mathrm{pH} \sim 5.0)$, at mesophilic temperature and using stressed inoculum. However, for some substrates like potato waste [31] or cotton stalk, optimal conditions [18] are closer to $\mathrm{pH}$ neutral or basic. Therefore, it is important to clarify these differences and determine conditions (including $\mathrm{pH}$, temperature, microaeration rate, etc.) that are optimal for hydrogen DF production for various available substrates and to scale up process into profitable range. Besides, it is also checked whether the upper temperature limit of mesophilic process (for various aeration rates) stimulates or inhibits hydrogen production [26]. At the same time we check how various considered conditions influence methane production. The studied issues as well as the investigated substrates are rarely discussed, or contradicting results are presented (e.g. pH level). The results obtained here were compared with data from earlier studies [32] for sour cabbage and cotton waste at higher $\mathrm{pH}$ value (7.54) and without inoculum stress.

\section{Materials and methods}

The fermentation process of cotton wastes was performed in batch reactors of volume $2 \mathrm{dm}^{3}$ with working volume 1.2 $\mathrm{dm}^{3}$. As inoculum, sludge from an agricultural biogas plant (Pomerania Region) was used, and $5 \mathrm{~g} \mathrm{VSS} / \mathrm{L}$ (VSS= volatile suspended solids) were applied to each batch of cotton waste. A substrate (load $5 \mathrm{~g}$ VSS/L), obtained from 100\% cotton lab coats, was milled and hydrolysed using $0.1 \mathrm{M}$ $\mathrm{HCl}$ acidic solution for $2 \mathrm{~h}$.

Initially, the inoculum was treated by heat shock for $0.5 \mathrm{~h}$ at $105^{\circ} \mathrm{C}$. Later, the initial $\mathrm{pH} 7.84$ was lowered by $\mathrm{HCl}$ to $\mathrm{pH} 5.0$ and applied to the DF process. The substrate was pretreated analogous to a Nasirian procedure for DF of wheat straw [33] but a $0.1 \mathrm{M}$ solution of $\mathrm{H}_{2} \mathrm{SO}_{4}$, which was the most efficient in the case of hydrogen production from their substrate [34], was replaced here by cheaper $\mathrm{HCl}$ (for $\mathrm{pH} 3$ ).

Then cotton and inoculum samples were added to the reactors. The temperatures 40 and $43^{\circ} \mathrm{C}$ (maximum temperature for mesophilic conditions [35] were maintained in the reactors. The oxygen flow rates (OFR) range from 0 to $1.0 \mathrm{~mL} / \mathrm{h}$ on average was provided for the fermentation process in the reactors. The oxygen was added twice a day (for approximately $2 \mathrm{~s}$ ) until the fermentation process was stopped.

All the experiments were carried out in triplicate, (see scheme of setup in Fig. 1). The biogas production was determined using the Owen method [36]. The qualitative and quantitative assessment of the gases produced was performed using a gas chromatograph (GC) with a thermal conductivity detector and argon as a carrier (gas flow rate was $0.6 \mathrm{~mL} / \mathrm{h}$ ). A Silco packed column Restek ${ }^{\circledast}$ with characteristics of $2 \mathrm{~m} / 2 \mathrm{~mm}$ ID $3 \mathrm{~mm}$ OD Silica was used. In order to determine the right amount according to Standard Methods [37], of fresh matter (FM) of inoculum and the substrate total solids (TS) [\%FM] and volatile solids (VSS) [\%TS] (determined to the [38]. The results are presented in Table 1.

Cotton wastes characteristics (TS, VSS) were determined before and after hydrolysis and after fermentations and drying. Cotton wastes were sieved by net with mesh $2 \mathrm{~mm}$ after hydrolysis and after DF (taking it from bottom of reactors). The changes of VSS were used to determined degree of utilization of cotton waste in agreement with norms [37, 38].

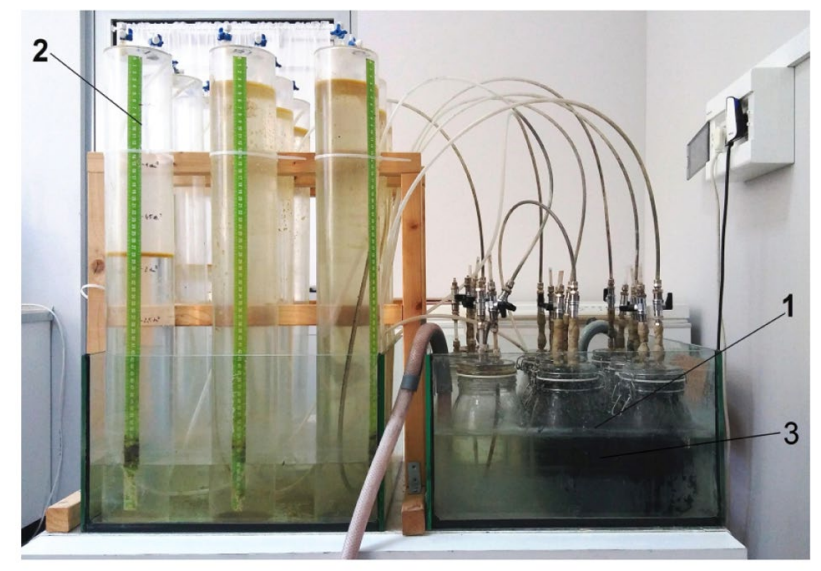

Fig. 1 Fermentation setup used in experiment: 1. glass reactors, 2. cylindrical vessel collecting biogas, 3 . water bath chamber enabling mesophilic conditions in reactors 
Table 1 Characteristics of inoculums and substrate

\begin{tabular}{llll}
\hline Material & $\mathrm{pH}$ & $\mathrm{TS}$ & \multicolumn{1}{l}{ VSS } \\
\hline Boiled inoculum & 7.84 & $1.5 \% \pm 0.03 \%$ & $37.91 \% \mathrm{TS} \pm 1.22 \%$ \\
Boiled inoculum after fermentation at $40{ }^{\circ} \mathrm{C}$ & 5.5 & $1.8 \% \pm 0.03 \%$ & $42.96 \% \mathrm{TS} \pm 1.02 \%$ \\
Boiled inoculum after fermentation at $43{ }^{\circ} \mathrm{C}$ & 5.9 & $1.2 \%+0.02 \%$ & $42.22 \% \mathrm{TS} \pm 1.12 \%$ \\
Cotton wastes & - & $98 \% \pm 0.02 \%$ & $98.29 \% \mathrm{TS} \pm 1.2 \%$ \\
Cotton waste after hydrolysis & - & $95 \% \pm 0.03 \%$ & $96 \% \mathrm{TS} \pm 1.03 \%$ \\
Cotton wastes after fermentation at $43{ }^{\circ} \mathrm{C}$ and drying [38] & 5.5 & $92.5 \% \pm 0.02 \%$ & $93.5 \% \mathrm{TS} \pm 1.02 \%$ \\
Cotton wastes after fermentation at $40^{\circ} \mathrm{C}$ and drying [38] & 5.9 & $91.4 \% \pm 0.02 \%$ & $92.6 \% \mathrm{TS} \pm 1.02 \%$
\end{tabular}

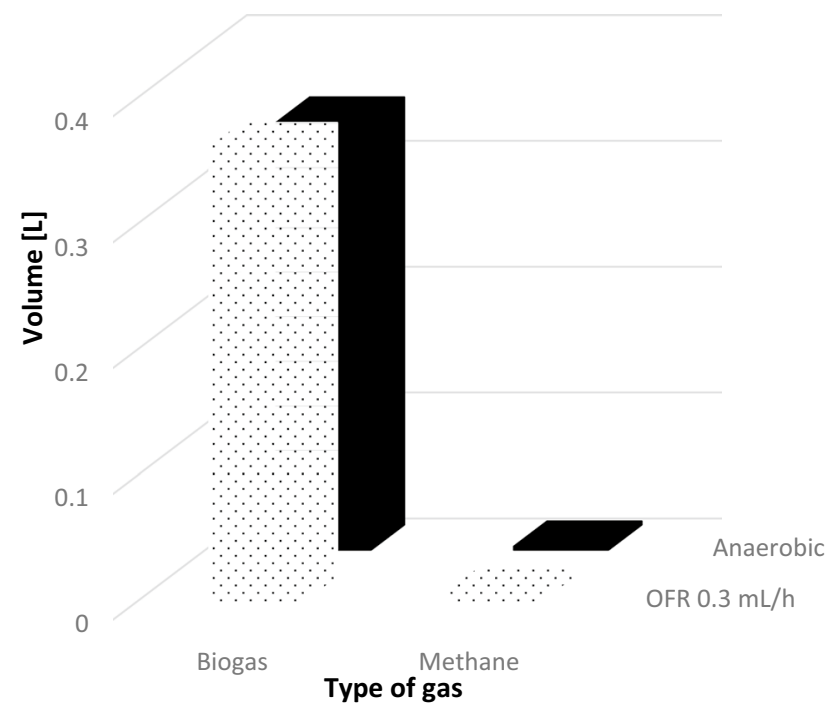

Fig. 2 Total biogas and hydrogen production obtained during fermentation process stimulated by pretreated inoculum, at $\mathrm{T}=40^{\circ} \mathrm{C}$ and OFR (oxygen flow rate) $0.3,0.8$ and $1 \mathrm{~mL} / \mathrm{h}$

\section{Results}

The GC spectra allowed determination of methane, hydrogen, carbon monoxide, carbon dioxide and nitrogen (from process initiation procedure) concentrations. The fermentation process with pretreated inoculum (initial $\mathrm{pH} \sim 5$ ) was continued for $5 \mathrm{~h}$ (later DF process had stopped) at temperature $40{ }^{\circ} \mathrm{C}$, while at $43{ }^{\circ} \mathrm{C}$ the fermentation process was continued for $45 \mathrm{~h}$.

In the case of boiled inoculum $(\mathrm{pH} \sim 8.5)$ biogas wasn't generated, so process at temperature of $43{ }^{\circ} \mathrm{C}$ was checked only for pretreated inoculum $(\mathrm{pH} \sim 5)$. In the case of process performed at temperature $40^{\circ} \mathrm{C}$ the biogas contained carbon dioxide, nitrogen and hydrogen (no methane generation was observed, in contrast to fermentation at $43{ }^{\circ} \mathrm{C}$ ). The hydrogen production strongly depends on OFR, see Fig. 2 for oxygen flow rates: $0.3,0.8$ and $1 \mathrm{~mL} / \mathrm{h}$.

The total biogas production equaled:

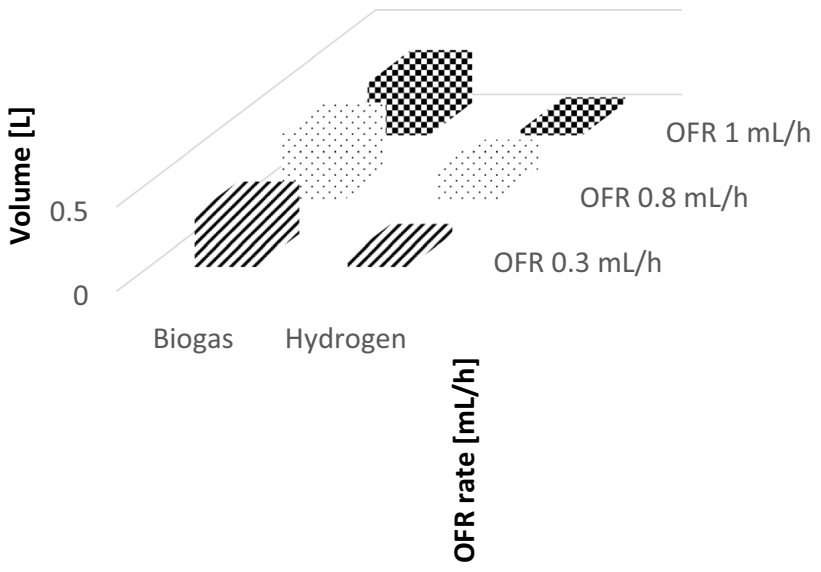

Type of Gas

Fig. 3 Total biogas and methane production fermentation process stimulated by pretreated inoculum, $\mathrm{T}=43^{\circ} \mathrm{C}$ for OFR $0.3 \mathrm{~mL} / \mathrm{h}$ and anaerobic conditions

- $0.31 \mathrm{dm}^{3}$ containing $18.9 \% \mathrm{H}_{2}\left(0.06 \mathrm{dm}^{3}\right)$ for OFR $0.3 \mathrm{~mL} / \mathrm{h}$;

- $0.39 \mathrm{dm}^{3}$ containing $42 \% \mathrm{H}_{2}\left(0.168 \mathrm{dm}^{3}\right)$ for OFR $0.8 \mathrm{~mL} / \mathrm{h}$;

- $0.31 \mathrm{dm}^{3}$ containing $10.3 \% \mathrm{H}_{2}\left(0.03 \mathrm{dm}^{3}\right)$ for OFR $1 \mathrm{~mL} / \mathrm{h}$.

After $5 \mathrm{~h}$ DF process terminated at $40{ }^{\circ} \mathrm{C}$ for all OFR rates. Thus the results are not presented in the form of cumulative hydrogen production versus time as is usual [39]. The optimum OFR value lies between 0.3 and $1 \mathrm{~mL} / \mathrm{h}$. Fast and effective hydrogen production has already been observed in dark fermentation but with lower rate e.g. in ref.[40], although it continued longer, even for $80 \mathrm{~h}$.

At fermentation temperature $43^{\circ} \mathrm{C}$, biogas comprises: methane, carbon dioxide and nitrogen. No hydrogen was registered. The strictly anaerobic of an oxygen flow rate $\sim 0.3 \mathrm{~mL} / \mathrm{h}$ conditions were compared-see Fig. 3 . Under strict anaerobic conditions $0.92 \%$ of methane $(0.003$ $\mathrm{dm}^{3}$ ) in $0.34 \mathrm{dm}^{3}$ of biogas was found after $45 \mathrm{~h}$ fermentation. In the case of OFR $0.3 \mathrm{~mL} / \mathrm{h}$, higher concentration 
of $1.7 \%$ of methane $\left(0.006 \mathrm{dm}^{3}\right)$ in biogas $\left(0.34 \mathrm{dm}^{3}\right)$ was measured.

The $\mathrm{pH}$ value in the case of fermentation at $40{ }^{\circ} \mathrm{C}$ changed from 5.0 to 5.5 , under condition of free $\mathrm{pH}$ evolution (no $\mathrm{pH}$ control measures applied-see e.g. [41]. In the case of fermentation at temperature $43^{\circ} \mathrm{C}$ the $\mathrm{pH}$ value increased to 5.9 after $45 \mathrm{~h}$ for all OFR values, i.e. $\mathrm{pH}$ value is higher in comparison to that at $40^{\circ} \mathrm{C}$.

The presented results showed that fermentation process (after heat shock pretreatment of inoculum) led to higher hydrogen production than in [42] (and no methane generation) at the lower temperature $40^{\circ} \mathrm{C}$. Actually at $43^{\circ} \mathrm{C}$ hydrogen was not generated in significant amount and methane at concentration below $2 \%$ of biogas.

\section{Discussion of results}

In this study DF proceeds under standard biogas inoculum condition in contrast to isolated bacterial consortium like in Li et al. [18]. It is worth adding that in the presented experiment there were not any nutrients like agar plates [43] or salts applied [44]. Moreover, the discussed process of hydrogen production is rather simple and not demanding; it proceeds without any bacteria isolation or hydrolysate separation. Thus, it is more economical than those already reported [45-48].

The process of cotton digestion slows down at higher temperature $43^{\circ} \mathrm{C}$ (the rate is 9 times lower) when compared with the case at $40^{\circ} \mathrm{C}$. The observed at $40^{\circ} \mathrm{C}$ hydrogen yields per day were higher than those reported by $\mathrm{Li}$ et al. [18]. The hydrogen production measured here was 6 times higher than in [49]. On the other hand biomass conversion is low $(2.6 \%), 0.9 \%$ lower than in production of methane from cotton waste at $43^{\circ} \mathrm{C}$ - see e.g. [22].

The experiments pointed to the importance of inoculum preatretment (thermal shock) and process temperature for hydrogen production rate. When DF temperature is higher methane production prevails, bacterial consortium is stimulated to generate methane (although in low quantities if compared to [22] even at low pH [50]. Similar results were reported by Chandra et al. [26] for rice straw anaerobic fermentation. Also Del et al. [51] concludes that stable mesophilic condition with temperature from the range $36-40{ }^{\circ} \mathrm{C}$ is necessary to keep process of hydrogen production continuing.
It was also found that in some cases after termination of hydrogen generation, methanogenesis continues e.g. when food and garden waste mixture is fermented at $37^{\circ} \mathrm{C}$ [52] or xylose fermented at $30^{\circ} \mathrm{C}$ [53]. However, it was not the case for cotton fermented here at $40^{\circ} \mathrm{C}$.

The results obtained here were compared with DF data for other substrates-see Table 2 . The hydrogen yields obtained here were larger than from cow dung pretreated using $2 \% \mathrm{HCl}$ solution [54], microalgal biomass [55] or sunflower pretreated by $4 \% \mathrm{HCl}$ [56] but less than $50 \%$ of hydrogen obtained from cotton stalk after pretreatment in $4 \% \mathrm{H}_{2} \mathrm{SO}_{4}$ and $121^{\circ} \mathrm{C}$ for 30 min. or $80 \%$ less than from aspen wood treated using $2 \% \mathrm{NaOH}$. Highest yields were obtained for cassava with addition of a-amylase and gluco-amylase after thermal pretreatment at $112^{\circ} \mathrm{C}$ for $15 \mathrm{~min}$ und using activated sludge by heat shock for $30 \mathrm{~min}$.

\section{Conclusions}

Cotton waste at load VSS $5 \mathrm{~g} / \mathrm{L}$ at $\mathrm{pH} 5.0$ was found to be a good source of hydrogen by mean of dark fermentation, when inoculum is stressed. The process is fast (short) and efficient. The discussed process of hydrogen production is rather simple and not demanding; it proceeds without any bacteria isolation or hydrolysate separation. Thus it is more economical than those already reported.

However, rather low conversion of cotton waste was observed, e.g. conversion of cotton waste in methanogenation $3.4 \%$ was higher than in hydrogenation process $2.6 \%$ and lower increase of bacterial biomass was registered. So, the process can be used for utilization of cotton wastes as fast preliminary stage of cotton waste utilization followed by methanisation.

The highest production was observed at OFR $0.8 \mathrm{~mL} / \mathrm{h}$ and DF process temperature $40^{\circ} \mathrm{C}$ i.e. $0.168 \mathrm{dm}^{3}$ of hydrogen- $42 \%$ of biogas content. Besides it was found that temperature is a relevant parameter of stimulating or inhibiting hydrogen production in DF. Methanogenesis can revive again after repeated heat shock treatment and temperature of fermentation increase to $43^{\circ} \mathrm{C}$ in the case of cotton.

Besides, it should be underlined that that the applied $5 \mathrm{~g} \mathrm{VSS} / \mathrm{L}$ should be probably increased in future studies to check the effects of load increase. The phenomena will be investigated further. 
Table 2 Comparison of hydrogen production from different substrates (batch process)

\begin{tabular}{|c|c|c|c|c|}
\hline $\begin{array}{l}\text { Type of substrate/pretreatment of } \\
\text { substrate }\end{array}$ & $\begin{array}{l}\text { Hydrogen Yield } \\
\text { ( } m L \mathrm{H}_{2} / \mathrm{g} \text { subs.) }\end{array}$ & Type of inoculum & Process conditions $\left(\mathrm{g} / \mathrm{L} /{ }^{\circ} \mathrm{C} / \mathrm{pH}\right)$ & Source \\
\hline Cotton waste/in $0.1 \mathrm{M} \mathrm{HCl}$ for $1 \mathrm{~h}$ & 34 & Heat shocked at $105^{\circ} \mathrm{C}$ for $30 \mathrm{~min}$ & (5/40/5.0 microaeration) & This study \\
\hline $\begin{array}{l}\text { Cotton stalk/in } 4 \% \mathrm{H}_{2} \mathrm{SO}_{4} \text { at } 121^{\circ} \mathrm{C} \text { for } \\
30 \mathrm{~min}\end{array}$ & 72.7 & $\begin{array}{l}\text { Bacteria from wild carp instentine/ } \\
\text { isolation broth medium }\end{array}$ & $40 / 37 / 8$ & [18] \\
\hline Sour cabbage/no pretreatment & 4.8 & Untreated sludge & (10/38/7.9 microaeration) & {$[57]$} \\
\hline $\begin{array}{l}\text { Reed canary grass/in } 3 \% \mathrm{HCl}, 121^{\circ} \mathrm{C} \text {, } \\
90 \mathrm{~min}\end{array}$ & 36 & Untreated sludge & $(5 / 38 / 3.4-6$ & {$[45]$} \\
\hline $\begin{array}{l}\text { Mixture of hydrothermally pretreated } \\
\text { asbestos to glucose in proportion } \\
1: 6\end{array}$ & 1.3 & $\begin{array}{l}\text { Activated sludge with stressing using } \\
\text { 2-Bromoethanesulfate }\end{array}$ & $(5 / 35 / 5.45)$ & [46] \\
\hline $\begin{array}{l}\text { Grass-comminuted } 10 \mathrm{~g} / \mathrm{l} 20 \text { mesh/in } \\
0.5 \% \mathrm{NaOH}, 105^{\circ} \mathrm{C} \text { for } 3 \mathrm{~h}\end{array}$ & 4.39 & $\begin{array}{l}\text { Sludge from cracked cereal baked for } \\
2 \mathrm{~h} \text { and boiled for } 30 \mathrm{~min}\end{array}$ & $(5 / 35 / 7.0)$ & [58] \\
\hline $\begin{array}{l}\text { Cassava/a-amylase }+ \text { gluco-amylase } \\
-/ \text { heat gelatinising/ at } 112^{\circ} \mathrm{C} \text { for } \\
15 \text { min }\end{array}$ & 240 & $\begin{array}{l}\text { Activated sludge heat shocked for } \\
30 \mathrm{~min}\end{array}$ & $(10 / 35 / 7.0)$ & {$[54]$} \\
\hline $\begin{array}{l}\text { Cow dung compost } / 2 \% \mathrm{HCl} \text { and } 8 \text {-min } \\
\text { microwaves }\end{array}$ & 0.5 & $\begin{array}{l}\text { Dung compost heat shocked at } \\
130^{\circ} \mathrm{C} \text { for } 2 \mathrm{~h}\end{array}$ & $(25 / 36 / 7.0)$ & {$[56]$} \\
\hline $\begin{array}{l}\text { Sunflower stalk /in } 4 \% \mathrm{HCl} \text { at } 170^{\circ} \mathrm{C} \\
\text { for } 1 \mathrm{~h}\end{array}$ & 2.3 & $\begin{array}{l}\text { Activated sludge heat-shocked at } \\
90^{\circ} \mathrm{C} \text { for } 15 \mathrm{~min}\end{array}$ & $(5 / 35 / 5.5)$ & {$[55]$} \\
\hline Microalgal biomass/ centrifuged & 20.9 & $\begin{array}{l}\text { Activated sewage sludge/by keeping } \\
\text { at } 4{ }^{\circ} \mathrm{C} \text { in solution } 15 \mathrm{~g} / \mathrm{L} \text { peptone } \\
\text { from casein, } 5 \mathrm{~g} / \mathrm{L} \text { peptone from } \\
\text { soymeal, and } 5 \mathrm{~g} / \mathrm{L} \text { sodium chloride } \\
\text { for } 3 \text { day and then heat shocked } \\
\text { for } 15 \mathrm{~min} \text { at } 121^{\circ} \mathrm{C} \text { and pressure } \\
1.4 \mathrm{bar}\end{array}$ & $(10 / 30 / 7)$ & [59] \\
\hline Aspen wood/in $2 \% \mathrm{NaOH}$ & 195 & $\begin{array}{l}\text { Hot spring culture, heat shocked at } \\
60^{\circ} \mathrm{C} \text { in } \mathrm{pH} 6.0\end{array}$ & $(1.23 / 50 / 7)$ & {$[60]$} \\
\hline $\begin{array}{l}\text { Depackaging wastes with glucose 1:6 } \\
\text { /heat treatment }\end{array}$ & 1.4 & $\begin{array}{l}\text { Activated sludge with stressing using } \\
\text { 2-Bromoethanesulfate } 10 \mathrm{mM}\end{array}$ & $(4 / 37 / 7)$ & {$[61]$} \\
\hline
\end{tabular}

Funding The research was funded from grant of Institute of FluidFlow Machinery, Polish Academy of Science in Gdansk FBW-44Solowski and The National Centre for Research and Development 'New renewable energy technologies for sustainable development of rural areas and low-carbon agriculture' BIOSTRATEG3/344128/12/ NCBR/2017.

\section{Compliance with ethical standards}

Conflict of interest The authors declare that they have no conflict of interest.

Open Access This article is licensed under a Creative Commons Attribution 4.0 International License, which permits use, sharing, adaptation, distribution and reproduction in any medium or format, as long as you give appropriate credit to the original author(s) and the source, provide a link to the Creative Commons licence, and indicate if changes were made. The images or other third party material in this article are included in the article's Creative Commons licence, unless indicated otherwise in a credit line to the material. If material is not included in the article's Creative Commons licence and your intended use is not permitted by statutory regulation or exceeds the permitted use, you will need to obtain permission directly from the copyright holder. To view a copy of this licence, visit http://creativecommons .org/licenses/by/4.0/.

\section{References}

1. Sasaki C, Kiyokawa A, Asada C, Nakamura Y (2019) Glucose and valuable chemicals production from cotton waste using hydrothermal method. Waste Biomass Valoriz 10:599-607

2. Aslanzadeh S, Rajendran K, Jeihanipour A, Taherzadeh MJ (2013) The effect of effluent recirculation in a semi-continuous twostage anaerobic digestion system. Energies 6:2966-2981

3. Halimi MT, Hassen MB, Sakli F (2008) Cotton waste recycling: Quantitative and qualitative assessment. Resour Conserv Recycl 52:785-791

4. Sołowski G (2016) Theoretical potential of hydrogen production from textiles wastes in pomeranian region by means of dark fermentation. In: Noch T, Saczuk J, Wesołowska A (eds) Globalizacja a regionalna ochrona srodowiska, 1st edn. Wydawnictwo GSW, Gdańsk, pp 313-317 (ISBN 9788389762795)

5. Byrne E, Kovacs K, Van Niel EWJ, Willquist K, Svensson SE, Kreuger E (2018) Reduced use of phosphorus and water in sequential dark fermentation and anaerobic digestion of wheat straw and the application of ensiled steam-pretreated lucerne as a macronutrient provider in anaerobic digestion. Biotechnol Biofuels 11:1-16

6. Méndez-Vázquez MA, Gómez-Castro Fl, Ponce-Ortega JM, Serafín-Muñoz AH, Santibañez-Aguilar JE, El-Halwagi MM (2017) Mathematical optimization of a supply chain for the production of fuel pellets from residual biomass. Clean Technol Environ Policy 19:721-734 
7. Nikolaidis P, Poullikkas A (2017) A comparative overview of hydrogen production processes. Renew Sustain Energy Rev 67:597-611

8. Kumari D, Singh R (2018) Pretreatment of lignocellulosic wastes for biofuel production: a critical review. Renew Sustain Energy Rev 90:877-891

9. Prabakar D, Suvetha KS, Manimudi VT, Mathimani T, Kumar G, Rene ER, Pugazhendhi A (2018) Pretreatment technologies for industrial effluents: critical review on bioenergy production and environmental concerns. J Environ Manage 218:165-180

10. Sarıdemir S, Ağbulut Ü (2019) Combustion performance vibration and noise characteristics of cottonseed methyl ester-diesel blends fuelled engine. Biofuels 10(1080/17597269):1667658

11. Ağbulut Ü, Sarıdemir S, Albayrak S (2019) Experimental investigation of combustion, performance and emission characteristics of a diesel engine fuelled with diesel-biodiesel-alcohol blends. J Brazilian Soc Mech Sci Eng 41:1-12

12. Ağbulut Ü, Sarıdemir S, Karagöz M (2020) Experimental investigation of fusel oil (isoamyl alcohol) and diesel blends in a $\mathrm{Cl}$ engine. Fuel 267:117042

13. Ağbulut Ü, Sarıdemir S (2018) A general view to converting fossil fuels to cleaner energy source by adding nanoparticles. Int J Ambient Energy. https://doi.org/10.1080/01430750.2018.15638 22

14. Ağbulut Ü, Karagöz M, Sarıdemir S, Öztürk A (2020) Impact of various metal-oxide based nanoparticles and biodiesel blends on the combustion, performance, emission, vibration and noise characteristics of a $\mathrm{Cl}$ engine. Fuel. https://doi.org/10.1016/j. fuel.2020.117521

15. Ağbulut Ü, Bakir H (2019) Düzce University Journal of Science \& Technology. Düzce Univ J Sci Technol 4:25-36

16. Guo M, Song W, Buhain J (2015) Bioenergy and biofuels: history, status, and perspective. Renew Sustain Energy Rev 42:712-725

17. Sandin G, Peters GM (2018) Environmental impact of textile reuse and recycling e A review. J Clean Prod 184:353-365

18. Li Y, Zhang Q, Deng L, Liu Z, Jiang H, Wang F (2018) Biohydrogen production from fermentation of cotton stalk hydrolysate by Klebsiella sp. WL1316 newly isolated from wild carp (Cyprinus carpio L.) of the Tarim River basin. Appl Microbiol Biotechnol 102:4231-4242

19. Koniuszewska I, Korzeniewska E, Harnisz M, Czatzkowska M (2020) Intensification of biogas production using various technologies: a review. Int J Energy Res. https://doi.org/10.1002/ er.5338

20. Kumar V, Longhurst $P$ (2018) Recycling of food waste into chemical building blocks. Curr Opin Green Sustain Chem 13:118-122

21. Patinvoh RJ, Taherzadeh MJ (2019) Fermentation processes for second-generation biofuels. Elsevier Inc., Amsterdam (ISBN 9780128151624)

22. Jeihanipour A, Aslanzadeh S, Rajendran K, Balasubramanian G, Taherzadeh MJ (2013) High-rate biogas production from waste textiles using a two-stage process. Renew Energy 52:128-135

23. Sołowski G, Konkol I, Cenian A (2019) Perspectives of hydrogen production from corn wastes in Poland by means of dark fermentation. Ecol Chem Eng S 26:255-263

24. Detman A, Mielecki D, Pleśniak $Ł$, Bucha M, Janiga M, Matyasik I, Chojnacka A, Jẹdrysek MO, Błaszczyk MK, Sikora A (2018) Methane-yielding microbial communities processing lactate-rich substrates: a piece of the anaerobic digestion puzzle. Biotechnol Biofuels 11:116

25. Hallenbeck PC, Abo-Hashesh M, Ghosh D (2012) Strategies for improving biological hydrogen production. Bioresour Technol 110:1-9

26. Chandra R, Takeuchi $H$, Hasegawa $T$ (2012) Hydrothermal pretreatment of rice straw biomass: a potential and promising method for enhanced methane production. Appl Energy 94:129-140

27. Sołowski G, Hrycak B, Czylkowski D, Konkol I, Pastuszak K, Cenian A (2019) Hydrogen and methane production under conditions of dark fermentation process with low oxygen concentration. In: Jibin K, Kalarikkal N, Thomas S, Nzihou A (eds) Re-Use and recycling of materials solid waste management and water treatment. River Publisher, Gistrup, pp 263-272 (ISBN 9788770220583)

28. Bahry H, Abdallah R, Chezeau B, Pons A, Taha S (2019) Biohydrogen production from carob waste of the Lebanese industry by dark fermentation fermentation. Biofuels. https://doi. org/10.1080/17597269.2019.1669862

29. Cieślik M, Dach J, Lewicki A, Smurzyńska A, Janczak D, PawlickaKaczorowska J, Boniecki P, Cyplik P, Czekała W, Jóźwiakowski K (2016) Methane fermentation of the maize straw silage under meso- and thermophilic conditions. Energy 115:1495-1502

30. Carrillo-Reyes J, Tapia-Rodríguez A, Buitrón G, Moreno-Andrade I, Palomo-Briones R, Razo-Flores E, Aguilar Juárez O, ArreolaVargas J, Bernet N, Maluf Braga AF et al (2019) A standardized biohydrogen potential protocol: an international round robin test approach. Int J Hydrogen Energy 44:26237-26247

31. Sekoai PT, Ayeni AO, Daramola MO (2019) Parametric optimization of biohydrogen production from potato waste and scale-up study using immobilized anaerobic mixed sludge. Waste and Biomass Valoriz 10:1177-1189

32. Sołowski G, Hrycak B, Czylkowski D, Pastuszak K, Konkol I, Cenian A (2018) Hydrogen and methane production under conditions of dark fermentation process with low oxygen concentration. In: Sabu T (ed) Proceedings of the International Conference on Reuse and Recycling (ICRM 2018), Kottayam, Kerala, India

33. Nasirian N, Almassi M, Minaei S, Widmann R (2011) Development of a method for biohydrogen production from wheat straw by dark fermentation. Int J Hydrogen Energy 36:411-420

34. Ghimire A, Valentino S, Frunzo L, Trably E, Escudié R, Pirozzi $F$, Lens PNL, Esposito G (2015) Biohydrogen production from food waste by coupling semi-continuous dark-photofermentation and residue post-treatment to anaerobic digestion: a synergy for energy recovery. Int J Hydrogen Energy 40:16045-16055

35. Sołowski G, Shalaby MS, Abdallah H, Shaban AM, Cenian A (2018) Production of hydrogen from biomass and its separation using membrane technology. Renew Sustain Energy Rev 82:3152-3167

36. Logan BE, Oh SE, Kim IS, Van Ginkel S (2002) Biological hydrogen production measured in batch anaerobic respirometers. Environ Sci Technol 36:2530-2535

37. Moriarty K (2013) Feasibility study of anaerobic digestion of food waste in St. Bernard, Louisiana: a study prepared in partnership with the environmental protection agency for the repowering America's land initiative: siting renewable energy on potentially contaminate. National Renewable Energy, Golden, pp 1-51

38. Sluiter A, Hames B, Ruiz R, Scarlata C, Sluiter J, Templeton D (2008) Determination of sugars, byproducts, and degradation products in liquid fraction process samples laboratory analytical procedure (LAP) issue date: 12/08/2006. National Renewable Energy Laboratory, Golden

39. Sołowski G, Konkol I, Hrycak B, Czylkowski D (2019) Hydrogen and methane production under conditions of anaerobic digestion of key-lime and cabbage wastes. Agritech 39:243-250

40. Pecorini I, Baldi F, lannelli R (2019) Biochemical hydrogen potential tests using different inocula. Sustain 11:1-17

41. Atasoy M, Eyice O, Schnürer A, Cetecioglu Z (2019) Volatile fatty acids production via mixed culture fermentation: revealing the link between $\mathrm{pH}$, inoculum type and bacterial composition. Bioresour Technol 292:121889 
42. Sołowski G, Konkol I, Cenian A (2020) Methane and hydrogen production from cotton wastes in dark fermentation process under anaerobic and microaerobic conditions. Biomass Bioenergy 2020.

43. García Depraect O, Muñoz R, van Lier JB, Rene ER, Diaz-Cruces $V F$, León Becerril E (2020) Three-stage process for tequila vinasse valorization through sequential lactate, biohydrogen and methane production. Bioresour Technol 307:123160

44. Keskin T, Arslan K, Nalakth Abubackar H, Vural C, Eroglu D, Karaalp D, Yanik J, Ozdemir G, Azbar N (2018) Determining the effect of trace elements on biohydrogen production from fruit and vegetable wastes. Int J Hydrogen Energy 43:10666-10677

45. Lakaniemi AM, Koskinen PEP, Nevatalo LM, Kaksonen AH, Puhakka JA (2011) Biogenic hydrogen and methane production from reed canary grass. Biomass Bioenerg 35:773-780

46. Spasiano D (2018) Dark fermentation process as pretreatment for a sustainable denaturation of asbestos containing wastes. J Hazard Mater 349:45-50

47. Pütün A, Özbay N, Önal E, Pütün E (2005) Fixed-bed pyrolysis of cotton stalk for liquid and solid products. Fuel Process Technol 86:1207-1219

48. Asfand S, Shah Y, Zeeshan M, Zohaib M, Ahmed N, lqbal N (2019) Co-pyrolysis of cotton stalk and waste tire with a focus on liquid yield quantity and quality. Renew Energy 130:238-244

49. Sołowski G, Konkol I, Cenian A (2020) Methane and hydrogen production from cotton waste by dark fermentation under anaerobic and microaerobic conditions. Biomass Bioenergy 138:105576

50. Fagbohungbe MO, Onyeri C, Adewale C, Semple KT (2019) The effect of acidogenic and methanogenic conditions on the availability and stability of carbon, nitrogen and phosphorus in a digestate. J Environ Chem Eng 7:103138

51. Del YA, Acosta A, Alvarez LH, Bernardo R, Reyes G, Teresa M, González G, Carrillo J (2020) Biocatalysis and Agricultural Biotechnology Addition of electron shuttling compounds and different $\mathrm{pH}$ conditions for hydrogen production by a heat-treated sludge. Biocatal Agric Biotechnol 23:101507

52. Blasco L, Kahala M, Tampio E, Vainio M, Ervasti S, Rasi S (2020) Effect of Inoculum pretreatment on the composition of microbial communities in anaerobic digesters producing volatile fatty acids. Microorganisms 8:581
53. Mockaitis G, Bruant G, Guiot SR, Peixoto G, Foresti E, Zaiat $M$ (2020) Acidic and thermal pre-treatments for anaerobic digestion inoculum to improve hydrogen and volatile fatty acid production using xylose as the substrate. Renew Energy 145:1388-1398

54. Su H, Cheng J, Zhou J, Song W, Cen K (2009) Improving hydrogen production from cassava starch by combination of dark and photo fermentation. Int J Hydrogen Energy 34:1780-1786

55. Monlau F, Aemig Q, Trably E, Hamelin J, Steyer JP, Carrere H (2013) Specific inhibition of biohydrogen-producing Clostridium sp. after dilute-acid pretreatment of sunflower stalks. Int J Hydrogen Energy 38:12273-12282

56. Fan YT, Zhang YH, Zhang SF, Hou HW, Ren BZ (2006) Efficient conversion of wheat straw wastes into biohydrogen gas by cow dung compost. Bioresour Technol 97:500-505

57. Sołowski G, Hrycak B, Czylkowski D, Pastuszak K, Cenian A (2018) Oxygen sensitivity of hydrogenesis' and methanogenesis'. In: Pikoń K, Lucyna C (eds) Contemporary problems of power engineering and environmental protection 2017. Gliwice, Department of Technologies and Installations for Waste Management Copyright, pp 157-159 (ISBN 978-83-950087-1-9)

58. Cui M, Shen J (2012) Effects of acid and alkaline pretreatments on the biohydrogen production from grass by anaerobic dark fermentation. Int J Hydrogen Energy 37:1120-1124

59. Batista AP, Gouveia L, Marques PASS (2018) Fermentative hydrogen production from microalgal biomass by a single strain of bacterium Enterobacter aerogenes-effect of operational conditions and fermentation kinetics. Renew Energy 119:203-209

60. Phummala K, Imai T, Reungsang A, Chairattanamanokorn P, Sekine M, Higuchi T, Yamamoto K, Kanno A (2014) Delignification of disposable wooden chopsticks waste for fermentative hydrogen production by an enriched culture from a hot spring. J Environ Sci (China) 26:1361-1368

61. Noblecourt A, Christophe G, Larroche C, Fontanille P (2018) Hydrogen production by dark fermentation from pre-fermented depackaging food wastes. Bioresour Technol 247:864-870

Publisher's Note Springer Nature remains neutral with regard to jurisdictional claims in published maps and institutional affiliations. 